AGRICULTURAL EDUCATION AND RESEARCH IN THE UNITED STATES.

$\mathrm{N}$ the latest bulletin of the Carnegie Foundation for the Advancement of Teaching ${ }^{1}$. an elaborate account is presented of the course of legislation in America which led to the foundation and endowment of the agricultural colleges and experiment stations. The former are known as the "land-grant" colleges, and this publication explains how this name arose. The foundation of these colleges, of which each of the States in America possesses at least one, dates from 1862, when the Morrill Act of that year appropriated the proceeds of six and one-third million acres of public lands for the purpose of founding in each State of the Union a College of "Agriculture and the Mechanic Arts." For many years after their foundation the land-grant colleges did not confine themselves to agriculture, and up to the close of the nineteenth century the number of students who graduated in agriculture was comparatively small.

In 1890 further endowments were voted by Congress, which by annual increments finally reached 5oool. per annum for each State in the Union. Again, in 1907 , the annual subvention to each State was raised to ro,oool, per annum. In the meantime a step of great consequence was taken, one which has done much to stimulate agricultural education and research in the United States. This was the establishment of experiment stations in connection with the land-grant colleges as a result of the famous Hatch Act of 1887 , which appropriated $3000 l$. per annum for each of these stations. By I906, when an Act was passed raising the appropriation for each station to 6oool., forty-eight of these stations had been established. Again, in 19I4, further appropriations were voted for college "extension" work, beginning with zoool. for each State, to be followed by annual increments of indefinite amount until the aggregate appropriations for this purpose in the whole country should reach a sum of $800,000 l$. But still Congress was not satisfied. By an Act passed this year further appropriations were sanctioned for the furtherance of agricultural education, which by 1926 will amount to $600,000 \%$. per annum. Excluding the appropriations in aid of extension work, the aggregate Federal grants in aid of higher agricultural education and research are now I, I75, oool. per annum. The individual States of the Union have also increased their aid pari passu, so that in 19I5 the total income of the colleges and experiment stations had reached the astonishing figure of $7,200,000$. The expenditure on higher agricultural education and research in England and Wales has a sorry appearance if contrasted with these remarkable figures. The normal State expenditure per annum in England and Wales is about 20,00ol. for higher education and 35, oool.

1 Bulletin No. ro, "Federal Aid for Vocational Education." By Dr. 1. L. Kandel. (New York City: Carnegie Foundation for the Advancement of 'Teaching.)

NO. 25 I2, VOL. IOO] for research, not much more than what one State in America receives for similar purposes.

The author of the bulletin under notice expresses some alarm at the rapidity of recent developments. He appears to think that there is still too much fluidity of opinion in regard to the scope and methods of vocational education, and that the money available will be squandered on unfruitful educational experiments. However that may be, it is surely a healthy sign that public opinion, as reflected by the Legislature, recognises the nesd for better scientific and technical training.

It is somewhat remarkable to find that attention. has been given to military training in the landgrant colleges ever since their foundation. Special officers are detailed to take charge of the instruction in military subjects.

A remarkable feature of the development of agricultural education in America is the sudden leap upwards which the number of students of agriculture has taken since I906. In that year the total number of students was nearly 3000 ; in 1914 the figure was nearly 15,000 . The bulletin fails to give any satisfactory reason for the suddenness with which the change set in. We venture to suggest that the demand for higher education in agriculture may have been stimulated by the extensive programme of demonstration fields upon which many of the States have recently embarked. These demonstration fields are designed to provide object-lessons of improved practice, and the extent to which they have been scattered over the country far surpasses anything that has ever been attempted here.

What is the lesson for this country from this record of American experience and progress? Surely, that we, too, should have faith and the courage to spend, especially on research. To begin with, some of the expenditure might be unfruitful, but one of the main obstacles to progress in the past has been the failure of agricultural research to attract the best scientific talent, a failure in large part due to the fact that the study of the sciences bearing on agriculture offered no career. Even as matters stand, the salaries of the teaching and research posts are inadequate, and in view of the rising demand for scientific work in the industries generally, the inadequacy is becoming more acute.

\section{DR. A. M. W. DOWNING, F.R.S}

DR. ARTHUR MATTHEW WELD DOWNING, whose death was announced in NATURE of December $x_{3}$, was born in Ireland on April I3, r85o, being the youngest son of the late Mr. A. M. Downing. He graduated at Trinity College, Dublin, where he gained the gold medal of his year in mathematics. He went soon afterwards to the Royal Observatory, Greenwich, where he was an assistant for twenty years. He was elected a fellow of the Royal Astronomical Society in 1875 , and of the Royal Society in 1896. 
$\mathrm{He}$ was secretary of the former society from 1889 to 1892 , and afterwards vice-president. He contributed seventy-five papers to it between 1877 and 19ro, which show the keen interest that he took in the improvement of the fundamental constants of astronomy. He revised Taylor's Madras Catalogue and made systematic comparisons of the Star Catalogues of Greenwich, the Capé, Washington, Cordoba, Melbourne, Hong-Kong, etc., with the object of deriving their systematic errors. He discussed the measures of the planetary diameters, and investigated the errors of the tabular orbits of Juno and Flora.

This work formed an admirable preparation for the post of superintendent of the Nautical Almanac Office, to which Dr. Downing was appointed in $r 892$ on the retirement of Dr. Hind. He retained this post for eighteen years, retiring early in Igro. During his tenure of office the solar and planetary tables of Newcomb and Hill replaced those of Le Verrier, the list of ephemeris stars was greatly enlarged, and Besselian coordinates were introduced into the eclipse and occultation sections, facilitating the accurate computation of these phenomena. The "Lunar Distance" tables were dropped, as practically obsolete in navigation, and their place was taken by the physical ephemerides of the sun, moon, and planets, the regular publication of which is a great convenience to observers. They were previously contributed to the Monthly Notices by Mr. Marth, and have led to an increase of our knowledge of the surface currents of Jupiter. Dr. Downing took part in the international conference of directors of ephemerides which met at Paris in 1896 to endeavour to attain uniformity in the adoption of astronomical constants: its efforts were partly successful, agreement being reached on the questions of precession, nutation, aberration, and solar parallax. He was one of the founders of the British Astronomical Association in I890, and was its second president (1892-94). He took part in two of the eclipse expeditions organised by it-to Vadso, Lapland, in I896, and to Plasencia, Spain, in rgoo.

Dr. Downing availed himself of the publication of the Cape Photographic Durchmusterung in I 899 to investigate the distribution of stars south of the equator, for which complete homogeneous material had previously been lacking. He found that the galactic condensation of the faint stars was greater in the southern hemisphere than in the northern. In conjunction with Dr. Johnstone Stoney he calculated the perturbations of the Leonid meteors between 1866 and 1899 . Their results were published too late to warn the public of the probable non-appearance of the shower in I899, so that considerable disappointment was caused, though the result was really in accord with calculation.

Dr. Downing spent the last few years in quiet retirement, owing to failing health. His tragically sudden death on December 8 resulted from angina pectoris. He leaves a widow and daughter.

\section{A. C. D. Crommelin.}

\author{
NOTES.
}

THE death of Mrs. Garrett Anderson on December I8, at eighty-one years of age, deprives the world of a pioneer whose persistent efforts opened to women the portals of institutions having the power to confer qualifications to undertake medical practice. She was the first woman to secure a medical diploma in this country, and she lived to see a steady stream of capable women enter the door which she was chiefly the means of opening. Mrs. Garrett Anderson was born in Lon. don in 1836 , and in 1860 began her medical studies with the view of obtaining an English qualification as a practitioner. No medical scheol of the metropolis would receive her as a student, and the Royal College of Surgeons, as well as the Royal College of Physicians, declined to allow her to sit for their examinations. She obtained, however, private tuition in anatomy and surgery, and studied at the London Hospital as a nurse; and after completing her course, was able to establish her claim to be examined by the Society of Apothecaries, which was compelled by its charter to admit to examination all persons, irrespective of sex, who presented themselves after passing through an approved course of study. She thus obtained the desired qualification of licentiate of the society, and began to practise medicine. In I 866 she opened a dispensary near Lisson Grove, Marylebone, and out of this undertaking grew the New Hospital for Women in the Euston Road, of which she remained senior physician until I89o. With Miss Jex-Blake, Mrs. Garrett Anderson endeavoured to induce the University of Edinburgh to grant medical degrees to women, but unsuccessfully. She went to France, however, and obtained the degree of doctor of medicine of the University of Paris in x870. The refusal of the northern University to admit women to its medical schools led to the establishment of the London School of Medicine for Women, and the alliance of this school with the Royal Free Hospital completed the provision for teaching required by the General Medical Council. From its foundation in 1876 until r898 Mrs. Garrett Anderson lectured to the students on medicine, and from $\mathrm{I}^{8} 8_{3}$ to 1903 acted as dean of the school. In $1896-97$ she was president of the East Anglian branch of the British Medical Association, and gave an address on "The Progress of Medicine in the Victorian Era." At Aldeburgh, Suffolk, which was her home for many years, she was elected mayor in 1908, and was the first woman to occupy such a post in England. In August last the honour of Commander of the Order of the British Empire was bestowed upon her by the King. Medical women will long cherish the memory of the pioneer to whose courage and strong character they largely owe the position now occupied by them.

THE student of natural science is continually surprised by the inaccuracies which appear when writers and artists in the general Press touch even the most elementary conceptions of the natural world in which we live. Mr. J. Reid Moir has just directed our attention to a remarkable case in a large advertisement published in various newspapers on December 4. It purports to be a reply to a question propounded in displayed type, "How did Man conquer the Dinosaurus?" and is made attractive by a sketch of a Diplodocus-like animal being attacked by primevál man. The most elementary acquaintance with geology would have assured the author that his question could never arise, because all the dinosaurs were extinct long before man appeared; and even if, presuming on little knowledge; he had mentally confused a dinosaur with a mammoth, he still made a fundamental mistake (as Mr. Moir points out) in providing the huntsman with a Neolithic implement.

NO. 25 I2, VOL. IOO] 